\title{
CLSPN wt Allele
}

National Cancer Institute

\section{Source}

National Cancer Institute. CLSPN wt Allele. NCI Thesaurus. Code C116690.

Human CLSPN wild-type allele is located in the vicinity of 1 p34.3 and is approximately $5 \mathrm{~kb}$ in length. This allele, which encodes claspin protein, plays a role in the G2 cell cycle checkpoint. 